\title{
Production and characterization of green gasoline obtained by thermal catalytic cracking of crude palm oil (Elaeis guineensis, Jacq.) in a pilot plant
}

Produção e caracterização de gasolina verde obtida por craqueamento térmico catalítico de óleo de palma bruto (Elaeis guineensis, Jacq.) em uma planta piloto

\author{
S. A. P. da Mota ${ }^{1 *}$; A. A. Mancio' ; L. E. P. Borges ${ }^{3} ;$ N. T. Machado ${ }^{4}$ \\ ${ }^{1}$ Faculdade de Engenharia de Materiais, Laboratório de Polímeros e Processos de Separação de Materiais, \\ Universidade Federal do Sul e Sudeste do Pará, CEP: 68505-080, Marabá-Pará-Brasil
}

${ }^{2}$ Programa de Pós-Graduação em Engenharia de Recursos Naturais da Amazônia, Universidade Federal do Pará, CEP: 66075-110, Belém-Pará-Brasil

${ }^{3}$ Laboratório de Preparação de Catalisadores e Craqueamento Catalítico, Seção de Engenharia Química, Instituto Militar de Engenharia, CEP: 22290-270, Rio de Janeiro-RJ-Brasil

${ }^{4}$ Faculdade de Engenharia Química Laboratório de Processos de Separação e Termodinâmica Aplicada(Term@), Universidade Federal do Pará, CEP: 66075-110, Belém-Pará-Brasil

*silviomota@unifesspa.edu.br

(Recebido em 15 de dezembro de 2016; aceito em 04 de janeiro de 2017)

\begin{abstract}
In this study was investigated the production and characterization of green gasoline obtained from crude palm oil (Elaeis guineensis, Jacq.), which was submitted at a process of thermal catalytic cracking in a pilot plant. The cracking reactions were carried out in a reactor of $143 \mathrm{~L}$, operating in batch mode at $450^{\circ} \mathrm{C}$ and atmospheric pressure, using $20 \%(\mathrm{w} / \mathrm{w})$ sodium carbonate $\left(\mathrm{Na}_{2} \mathrm{CO}_{3}\right)$ as catalyst. The organic liquid product (OLP) obtained in the cracking was submitted the distillation in laboratory scale using a column vigreux type. The results show that the yields in OLP obtained in the presence of $\mathrm{Na}_{2} \mathrm{CO}_{3}$ were of $65.86 \%$, with acid value of $1.02 \mathrm{mg} \mathrm{KOH} / \mathrm{g}$ and an elevated formation of gas residual. In relating to the green gasoline this presented a low kinematic viscosity value of $0.72\left(\mathrm{~mm}^{2} . \mathrm{s}^{-1}\right)$ and acid value of $1.11 \mathrm{mg}$ $\mathrm{KOH} / \mathrm{g}$. GC-MS analysis indicated in chemical composition of the green gasoline a percentage of $52.76 \%$ of hydrocarbon, of these $15.78 \%$ are paraffinic compounds, $31.54 \%$ of olefin, $3.50 \%$ of naphthenic and $1.94 \%$ of aromatic compounds.

Keywords: Thermal Catalytic Cracking, Palm Oil, Green Gasoline
\end{abstract}

Neste trabalho foi investigado a produção e caracterização de gasolina verde obtida a partir de óleo de palma bruto (Elaeis guineensis, Jacq.), o qual foi submetido a um processo de craqueamento térmico catalítico em uma planta piloto. A reação de craqueamento foi realizada em um reator de $143 \mathrm{~L}$, operando em modo descontínuo a $450^{\circ} \mathrm{C}$ e pressão atmosférica, utilizando como catalisador o carbonato de sódio $\left(\mathrm{Na}_{2} \mathrm{CO}_{3}\right)$ a $20 \%(\mathrm{p} / \mathrm{p})$. O produto líquido orgânico (PLO) obtido no craqueamento foi submetido a destilação em escala laboratorial utilizando uma coluna do tipo vigreux. Os resultados mostram que, o rendimento em PLO obtido na presença de $\mathrm{Na}_{2} \mathrm{CO}_{3}$ foi de $65,86 \%$, com acidez de $1,02 \mathrm{mg} \mathrm{KOH} / \mathrm{g}$ e uma elevada formação de gás residual. Em relação a gasolina verde, esta apresentou baixa viscosidade cinemática cerca de $0,72\left(\mathrm{~mm}^{2} \cdot \mathrm{s}^{-1}\right)$ e um valor de acidez de $1,11 \mathrm{mg} \mathrm{KOH} / \mathrm{g}$. A análise GC-MS indicou na composição química da gasolina verde uma percentagem de 52,76\% de hidrocarbonetos, destes $15,78 \%$ são compostos parafínicos, $31,54 \%$ de olefina, 3,50\% de nafténicos e 1,94\% de compostos aromáticos. Palavras-chave: Craqueamento Térmico Catalítico, Óleo de Palma, Gasolina Verde

\section{INTRODUCTION}

The Earth Planet, has suffered big changes, physical and chemical, economic changes, social and environmental, due to population increase and an elevated dependence of fossil fuels [1]. The production routes of biofuels, such biodiesel and bio oils (bio-gasoline and green diesel), are being improved so they can substitute partially or totally the oil and its derivatives [2]. Such 
biofuels are used mainly on transport vehicles, as well as in electrical energy generator engines [3].

The oils or triacylglycerols (TAG) and animal fat, pure or modified, has been applied on many ways of chemical products production, such as lubricants, biofuels, coatings, structural adhesives and others [4]. The application follows three strategies: the direct use on engines [5], the transesterification [6] and the cracking [7, 11, 12]. The process of cracking or pyrolysis is one of the most important processes on the oil refinery industry; the process is also useful on the production of biofuels obtained through biomass $[8,11,12]$.

The pyrolysis or cracking of TAG, consists on the thermal decomposition of this raw material on the absence of oxygen or of any other oxygenated compounds $[8,9]$, as well as on the presence or absence of catalysts, resulting on a blend of compounds, mostly by linear hydrocarbons $[2,9,10]$. The process of cracking of vegetal oils is realized with the objective of to produce biofuels, that is, fractions of hydrocarbons that are similar to gasoline, kerosene and to diesel, of fossil origin [3]. Botton et al. (2012) [9] report about the disadvantage of the process cracking, due to its high acidity index, due to fatty acids with short chains.

Mancio et al. (2016) [10] studied the influence of catalyst content on the physical-chemical properties, yield, and chemical composition of organic liquid products (OLP) obtained by thermal catalytic cracking of palm oil (Elaeis guineensis, Jacq.). The experiments were carried in batch mode at $450{ }^{\circ} \mathrm{C}$ using $5 \%, 10 \%, 15 \%$, and $20 \%(\mathrm{w} / \mathrm{w}) \mathrm{Na}_{2} \mathrm{CO}_{3}$ as the catalyst. The chemical composition of OLP was determined by gas chromatography-mass spectrometry (GCMS). As the catalyst content increased, the kinematic viscosity of OLP decreased from 6.59 to $3.63 \mathrm{~mm}^{2} \mathrm{~s}^{-1}$ and the acid value from 51.56 to $1.26 \mathrm{mg} \mathrm{KOH} / \mathrm{g}$. The GC-MS analysis showed that OLP comprise hydrocarbons (normal paraffin, olefin, and naphthenic) and oxygenated compounds (carboxylic acids, alcohols, ketones, and esters).

Ahmad et al. (2016) [11] studied the production of biofuels from palm oil from the cracking reaction, using as catalyst some zeolites materials, that facilitated the selective conversion of substrates to green gasoline. In this study, the zeolite material $\mathrm{Fe}-\mathrm{Zn}-\mathrm{Cu}-\mathrm{ZSM}-5$ showed greater efficiency with yield of 59\%, which can be assigned to higher content of loaded metal oxides as compared to the other synthesized catalysts.

Wiggers et al. (2009) [12] realized a thermal cracking of soy oil and fry oil at $525^{\circ} \mathrm{C}$ obtaining as results, products similar to gasoline and fractions of petroleum diesel. Dandik and Aksoy (1998) [13] measured the conversion of residual sunflower oil by cracking with temperatures between 400 and $420^{\circ} \mathrm{C}$, using as catalysts, the sodium carbonate, aluminium silicate and HZSM-5, with the obtaining maximum percentage of liquid hydrocarbons about $32.8 \%$, being confirmed the presence of hydrocarbons on the range of gasoline.

Twaiq et al. (2004) [14], studied the performance of materials containing ZSM-5 on the palm oil cracking, being those performances compared to HZSM-5 and MCM-41 catalysts, obtaining as result a conversion of the palm oil equal to $80 \%$ and a gasoline fraction yield of 38 to $47 \%$.

In this work, the objective was to study the production and characterization of green gasoline, obtained by thermal catalytic cracking of crude palm oil (Elaeis guineensis, Jacq.) in a pilot plant using sodium carbonate as catalyst.

\section{MATERIAL AND METHODS}

\subsection{Materials}

Crude palm oil (Elaeis guineensis Jacq) was provided by Engefar Ltda (Ananindeua-ParáBrazil). The crude palm oil has been physical-chemically characterized as described at Mota et al. (2014) [15] The sodium carbonate $\left(\mathrm{Na}_{2} \mathrm{CO}_{3}\right)$, commercial soda ASH Light (D50), with purity of $98.0 \%$ (wt.) was the catalyst used in this work. It was supplied by Solvay Chemicals International SA (Brussels, Belgium) and has been characterized by FTIR spectroscopy, X-Ray diffraction and thermal analysis (thermal gravimetric analysis and differential thermal analysis) as described in the literature [15].

\subsection{Experimental apparatus}




\subsubsection{Thermal catalytic cracking pilot plant}

The experimental apparatus used in performing this work was a Thermal Catalytic Cracking Pilot Plant (Fig. 1), where the main equipment is the sludge bed reactor of carbon stainless steel with a capacity of $143 \mathrm{~L}$. Mota et al.(2014) [15] describe in detail the pilot plant used in this study.

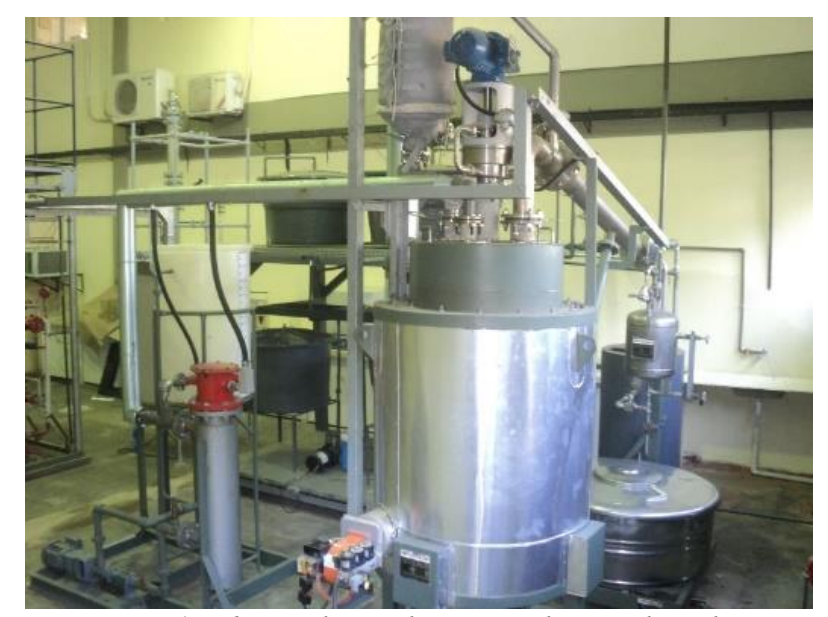

Figure 1: Thermal Catalytic Cracking Pilot Plant.

\subsubsection{Distillation laboratory unit}

The OLP was distilled into four fractions, in this paper we will present only the data of green gasoline. In the distillation laboratory used an experimental apparatus, consisting of an electrical heating mantel of $315 \mathrm{~W}$ (Quimis, Model: Q321A25/515), thermostatically controlled, a $1000 \mathrm{ml}$ round bottom, three neck glass flask with outer joints of borosilicate, angled $20^{\circ}, 24 / 40$ sides, one side used to insert a long thin thermocouple of a digital thermometer and the other to collect samples, 24/40 center, connected to a distillation column (Vigreux) of three stages of borosilicate, bottom inner and top outer joint 24/40, connected to a Liebig condenser of borosilicate, bottom inner and top outer joint $24 / 40$, of $700 \mathrm{~mm}$ length, attached to a borosilicate separator funnel of $250 \mathrm{ml}$, top outer 24/40 joint and glass Stopcock 19/38, and a crythermostatic bath (Quimis, Model Q214M2).

\subsection{Experimental procedures}

\subsubsection{Thermal catalytic cracking}

The experimental procedure thermal catalytic cracking of crude palm oil to obtain Organic Liquid Product (OLP) was performed as described by Mota et al.(2014) [15] under the following conditions: $450^{\circ} \mathrm{C}, 1 \mathrm{~atm}$ and $20 \%(\mathrm{w} / \mathrm{w})$ of sodium carbonate as the catalyst.

\subsubsection{Distillation of the OLP}

After obtaining the OLP, this was subjected to a bench scale distillation using a vigreux column with three stage. In order to obtain a mixture of hydrocarbons in the gasoline range (bio-gasoline), the OLP was distilled in distillation ranges from 40 to $175^{\circ} \mathrm{C}$, according to data found in literature [16, 17].

The OLP was heated gradually to enter in the distillation temperature range (40 to $\left.175^{\circ} \mathrm{C}\right)$. Then, the distilled fraction was collected in a separator funnel with $250 \mathrm{ml}$ capacity and stored in an amber glass bottles, as shown in Fig.2. The experimental procedure of fractional distillation of OLP consisted of five batches, aiming to obtain an 
amount of fractions previously fixed for the analysis of physical-chemical characterization and composition.

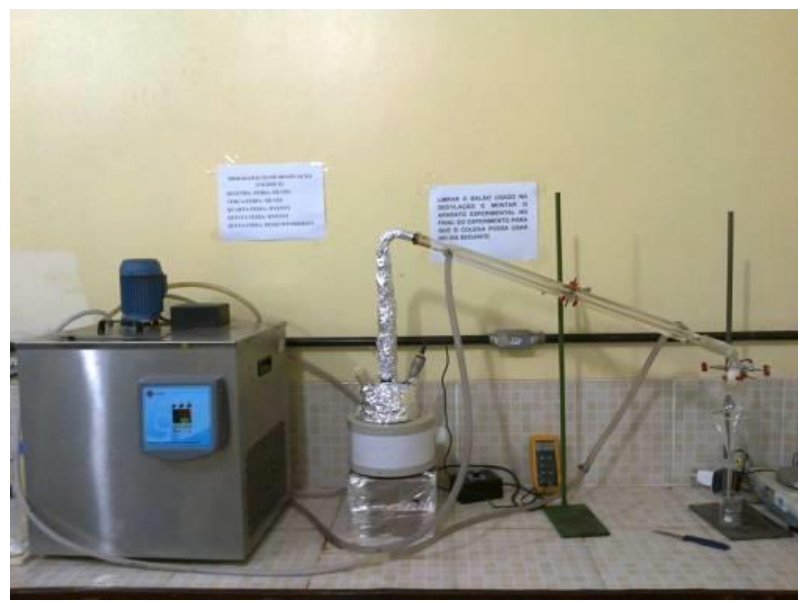

Figure. 2: System of fractional distillation with thermal insulation.

2.3.3. Mass balance of the distillation process

It was applied the Eq. (1) to find out the yield of the distilled fraction green gasoline, as well as bottom products for all the distillation batches.

$$
\text { Yield in distilled fractions [\%wt.] }=\frac{m_{D F}}{m_{O L P}} \times 100
$$

Where $m_{D F}$ is the mass of distilled fractions $(\mathrm{kg})$, and $m_{O L P}$ is the mass of organic liquid products $(\mathrm{kg})$.

\subsection{Characterization of the distilled fraction}

\subsubsection{Physical-chemical characterization}

The distilled fractions obtained after distillation have been physical-chemically characterized according to AOCS and ASTM official methods for Acid Value (AOCS Cd 3d63), Content of FFA (AOCS Ca 5a-40), Saponification Value (AOCS Cd 3-25), Density at $25^{\circ} \mathrm{C}$ (ASTM D 854), Refractive Index (AOCS Cc 7-25), Kinematics Viscosity (ASTM 446 and ASTM D 2515), Flash Point (ASTM D93), Corrosiveness to Copper (ASTM D 130), carbon residue (ASTM D 4530) and Ester value, which is the difference between the saponification value and the acid value as described by Mancio et al. (2016) [10].

\subsubsection{FT-IR spectroscopy}

The distilled fractions have been analyzed by FT-IR Spectroscopy using a spectrometer (Shimadzu/Model: Prestige 21). The absorbance spectra were obtained within the interval 4000 $-400 \mathrm{~cm}^{-1}$ and resolution of $16 \mathrm{~cm}^{-1}$ with the aid of a $\mathrm{KBr}$ Window. The samples were dropped onto the $\mathrm{KBr}$ surfaces by using micropipettes in order spread the liquid to produce a uniform layer.

\subsubsection{Distillation curve}

The distillation curves of the distilled fractions have been obtained according to the official method (ABNT/NBR 9619) using an automatic distillation apparatus (TANAKA, Model: AD6). 


\subsubsection{GC-MS analysis}

The GC-MS analysis of the distilled fractions was performed using a gas chromatograph coupled to a mass spectrometer (Shimadzu, Model: GCMS-QP2010 Plus), equipped with a capillary $30 \mathrm{~m} \times 0.25 \mathrm{~mm}$ ID fused silica open tubular column (Rtx-5MS) coated with $0.25 \mu \mathrm{m}$ (5\% diphenyl-95\% dimethyl-polysiloxane). SPME (solid phase microextraction) was performed using a manual micro-syringe, passing the needle through the sample vial septum, followed by exposure of a polymer-coated fused silica microfiber (PDMS-100 m) into the liquid sample. After adsorption of volatiles and semi-volatiles analytes, the microfiber was inserted into the GC-MS injection port to desorb the analytes onto the column. The carrier gas was hydrogen with a flow rate of $1.0 \mathrm{ml} / \mathrm{min}$, split rate of $1 / 5$, and the following temperature program was applied: Oven temperature $313 \mathrm{~K}$; linear heating from 313 to $523 \mathrm{~K}(10 \mathrm{~K} / \mathrm{min})$. The injector and detector temperatures were $493 \mathrm{~K}$ and $513 \mathrm{~K}$, respectively. To identify chemical compounds was performed with the aid the GC-MS solution Software and the NIST and Wiley Mass Spectral Libraries.

\section{RESULTS AND DISCUSSION}

\subsection{Crude palm oil physical-chemical analysis}

The crude palm oil was characterized, and the results are shown in the Table 1.

Table 1: Physical-chemical properties of palm oil.

\begin{tabular}{lc}
\hline \multicolumn{1}{c}{ Physical-Chemical Analysis } & This Work \\
\hline Density (Kg/m & 900.00 \\
Kinematic viscosity $\left(\mathbf{m m}^{\mathbf{2}} \mathbf{s}^{-\mathbf{1}}\right)$ & 48.05 \\
Acid value (mg KOH/g) & 4.80 \\
Saponification Index (mg KOH/g) & 179.90 \\
Index ester (mg KOH/g) & 174.60 \\
Refractive Index AD & 1.46 \\
Content of FFA* (\%) & 2.41 \\
\hline
\end{tabular}

*FFA - Free fatty acids.

The crude palm oil presented physical-chemical properties in accordance to the Brazilian National Agency of Sanitary Vigilance (1999) [27], as well as to the physical chemical properties found at Akinola et al (2010) [18]. With the analysis of infrared of the palm oil, verified the presence of characteristic bands of functional groups such esters and carboxylic acids, which were confirmed by the presence of bands typical of those functions. Bands corresponding the range of $1300-1000 \mathrm{~cm}^{-1}$ related to vibrations of $\mathrm{CO}$ axial deformation of esters, were observed. Also axial deformation bands $\mathrm{CC}(=\mathrm{O})-\mathrm{O}$ - of esters of the $\alpha, \beta$ unsaturated between 1300-1160 $\mathrm{cm}^{-1}$, and the bands between 1734 and $1751 \mathrm{~cm}^{-1}$, as well as, saturated aliphatic esters occurring between 1750 and $1735 \mathrm{~cm}^{-1}$, the presence of carboxylic acids due to band width between axial strain $\mathrm{OH}\left(3300\right.$ and $\left.2500 \mathrm{~cm}^{-1}\right)$, as well as the presence of the bands between $752-582 \mathrm{~cm}^{-1}$ vibrations characterized as being angled out of plane deformation $\mathrm{CH}$ referring mononucleate aromatic compounds.

\subsection{Characterization of the catalyst}

The characterization of the catalyst, has been described by Mota et al. (2014) [15] and Mancio et al. (2016) [10]. The analysis shows characteristic bands of vibrations for the anion $\mathrm{CO}_{3}^{-2}$, comprised between 1800 and $400 \mathrm{~cm}^{-1}$, characteristic of carbonates of alkali metals and alkaline earth metals, in the X-ray diffraction analysis of the sodium carbonate, the compounds were identified according to the position $2 \theta$ for the most intense peak: $100 \%\left(38.05^{\circ}\right)$ with spacing 2.36 ; $93 \%\left(37.92^{\circ}\right)$ with spacing of $2.37,90 \%\left(35.27^{\circ}\right)$ with spacing of 2.54 and $84 \%$ (32.34 ) with a spacing of 2.76 according to the file catalogs PDF 37-0451 and 08-0448. 


\subsection{Mass balances of the thermal catalytic cracking}

The results of the parameters used in the cracking reaction of the crude palm oil expressed through mass balance of product, are described at Mota et al. (2014) [15]. It may be noted also that, the yield of the cracking reaction of palm oil, catalysed by $\mathrm{Na}_{2} \mathrm{CO}_{3} 20 \%$ (wt), in this work, was higher than the yield parameter of OLP, compared with data of the literature, for example, Mancio et al. (2016) [10] and Umakanta et al. (1998) [19], which used $\mathrm{Na}_{2} \mathrm{CO}_{3}$ at $20 \%$ and 5\% in the cracking reaction of the crude palm oil and oil Spirulina platensis, respectively, achieving a yield of $42 \%$ and $51.6 \%$ in liquid biofuel (OLP) respectively.

Table 2 shows the results of parameters obtained in the distillation step of the OLP, which was generated in the cracking reaction using $\mathrm{Na}_{2} \mathrm{CO}_{3} 20 \%(\mathrm{w} / \mathrm{w})$ as well as the number of distillations performed. It should be emphasized that after the completion of the distillation, the distillate products related to gasoline range $\left(40-175^{\circ} \mathrm{C}\right)$ second $[16,17]$, were mixed for subsequent analysis.

Table 2: Parameters obtained in laboratory scale distillations.

\begin{tabular}{lccccc}
\hline \multirow{2}{*}{ Process Parameters } & \multicolumn{5}{c}{ batch } \\
\cline { 2 - 6 } & $\mathbf{1 s t}$ & $\mathbf{2}^{\text {nd }}$ & 3rd & 4th & 5th \\
\hline Initial mass of OLP(g) & 633.72 & 786.67 & 722.65 & 615.73 & 653.37 \\
Initial time of operation $(\mathbf{h})$ & $16: 37$ & $14: 04$ & $16: 12$ & $13: 04$ & $15: 00$ \\
Initial temperature of operation $\left({ }^{\circ} \mathbf{C}\right)$ & 27 & 28 & 35 & 30 & 91 \\
Initial time of distillation $(\mathbf{h})$ & $16: 48$ & $14: 18$ & $16: 22$ & $13: 18$ & $15: 12$ \\
Initial temperature of distillation $\left({ }^{\circ} \mathbf{C}\right)$ & 122 & 130 & 112 & 105 & 102 \\
Final time of operation $(\mathbf{h})$ & $17: 55-$ & $15: 15$ & $17: 36$ & $14: 43$ & $16: 35$ \\
Final temperature of operation $\left({ }^{\circ} \mathbf{C}\right)$ & 175 & 175 & 175 & 175 & 175 \\
Green gasoline mass $(\mathbf{g})$ & 39.82 & 17.44 & 33.75 & 39.39 & 31.69 \\
Yield (\%) & 6.28 & 2.21 & 4.67 & 6.39 & 4.85 \\
\hline
\end{tabular}

In relation to the initial temperature of the distillation of the OLP, it can be reported that, it is suffered variations, with values between $102^{\circ} \mathrm{C}$ to $130^{\circ} \mathrm{C}$, due a different distribution ranges of hydrocarbons in the sample collected after the thermal catalytic cracking. Moreover, it was observed that in the cracking reaction in this work, when compared with data found in the literature, at relation to mass yield in gasoline fraction, this is was very low, confirming the specificity of sodium carbonate to form hydrocarbons of long-chain. For example in Twaiq (2004) [14], which obtained a yield of 38 to $47 \%$ at gasoline fraction using ZSM-5 as catalyst, while in the present study it was obtained only $10 \%$ of green gasoline.

\subsection{Physical and chemical properties of the products}

The data in Table 3 show the physical-chemical properties of the OLP produced in the pilot plant and distilled fraction (green gasoline). 
Table 3: Physical-chemical properties of the products obtained after the thermal catalytic cracking and distillation.

\begin{tabular}{|c|c|c|}
\hline Process Parameters & $\begin{array}{c}\text { Cracking } \\
\text { OLP }\end{array}$ & $\begin{array}{c}\text { Fraction } \\
\text { Green gasoline }\end{array}$ \\
\hline Density $\left(\mathrm{kg} / \mathrm{m}^{3}\right)$ & 790.00 & 690.00 \\
\hline Viscosity $\left(\mathrm{mm}^{2} \mathrm{~s}^{-1}\right)$ & 2.02 & 0.72 \\
\hline Acid value ( $\mathrm{mg} \mathrm{KOH} / \mathrm{g}$ ) & 1.02 & 1.11 \\
\hline Saponification numbe (mg KOH/g) & 14.35 & 12.96 \\
\hline Ester content ( $\mathrm{mg} \mathrm{KOH/g)}$ & 13.33 & 11.85 \\
\hline FFA content $(\%)$ & 0.51 & 0.55 \\
\hline Refractive index & 1.44 & 1.40 \\
\hline Flash point $\left({ }^{\circ} \mathbf{C}\right)$ & 85.10 & 2.10 \\
\hline corrosivity & $1 \mathrm{~A}$ & $1 \mathrm{~A}$ \\
\hline Carbon residue (\%) & 0.64 & n.r \\
\hline
\end{tabular}

FFA - Free fatty acids; n.r. - not rated.

\subsection{Infrared of the products}

The results of the infrared spectra of palm oil, of the organic liquid product (OLP) and of the green gasoline (Fig. 3) reflected the appearance and disappearance of the bands associated with functions such as esters, carboxylic acids, hydrocarbons in the conversion of palm oil to OLP and then green gasoline. They enable the analysis of the behave or of physical-chemical properties of the products obtained. As previously described in item 2.4, the infrared spectrum of the oil showed characteristic bands of esters, as well as broad-band characteristics in position and carboxylic acid $\left(3468,2927\right.$ and $\left.1748 \mathrm{~cm}^{-1}\right)$. 


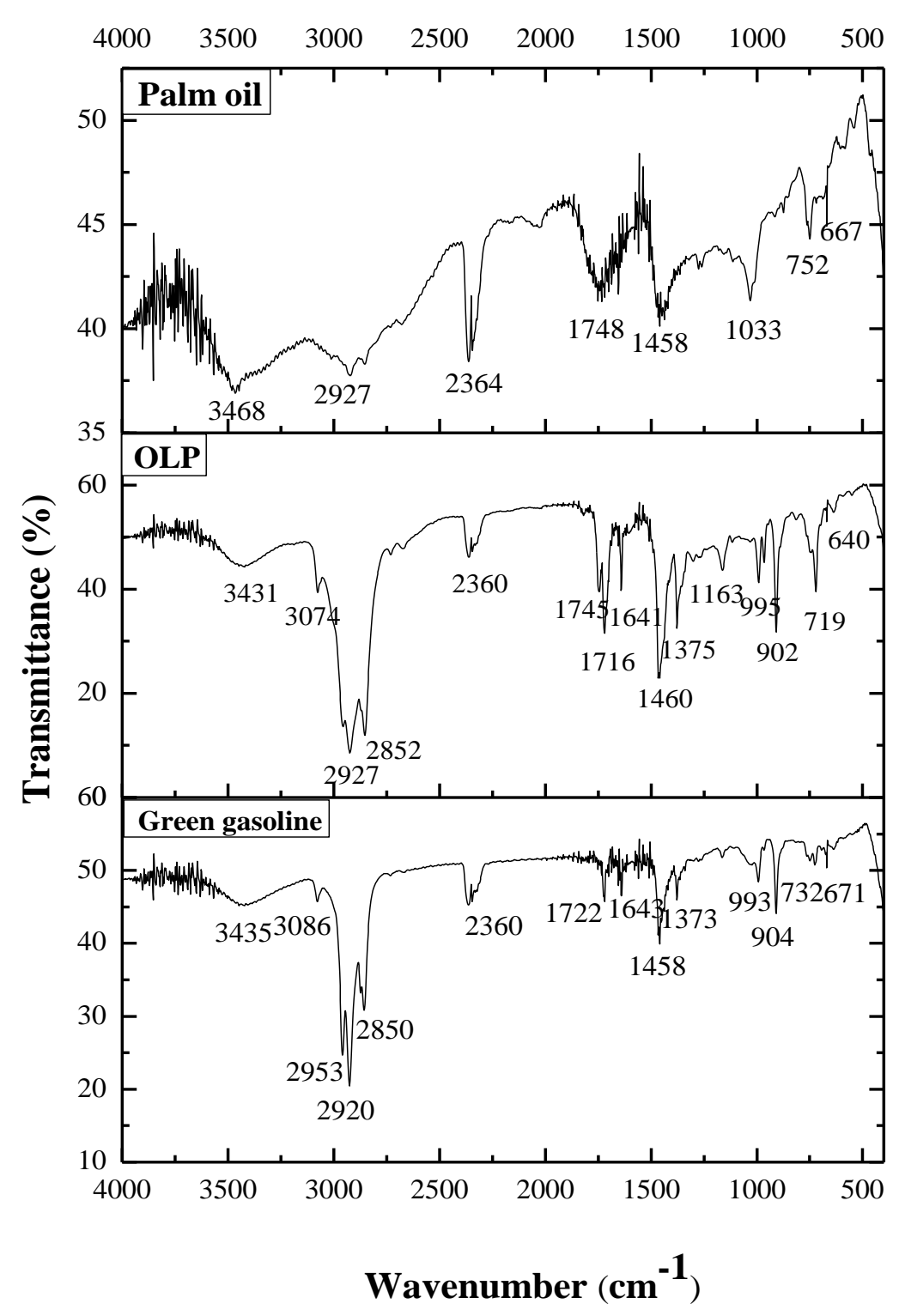

Figure 3: Infrared spectrum of palm oil, OLP and green gasoline before and after Thermal Catalytic Cracking and after distillation.

In the spectrum of OLP produced is emphasized the displacement or disappearance of some bands, especially those esters of the corresponding triglycerides, such as bands $1748 \mathrm{~cm}^{-1}$, $1164-1031 \mathrm{~cm}^{-1}$ as well as esters of secondary alcohols which occurs more or less at $1100 \mathrm{~cm}^{-1}$. In addition to these aforementioned bands between 1734 and $1751 \mathrm{~cm}^{-1}$, which correspond to the presence of aliphatic saturated occurring between 1750 and $1735 \mathrm{~cm}^{-1}$. Due to this displacement, the appearance of bands such as 1375,1722 and $1716 \mathrm{~cm}^{-1}$, corresponding to functions of carboxylic acids, ketones, and hydrocarbons, confirming the breakdown of triglyceride molecules, and the formation of oxygenated and non-oxygenated, as a function of cracking primary $[22,23]$. The presence of bands between $3000-2840 \mathrm{~cm}^{-1}$ corresponding to the normal alkane hydrocarbons function associated with the presence of these $1375 \mathrm{~cm}^{-1}$ band relating to the deformation vibration of $\mathrm{CH}$ angular methyl groups, confirms the presence of the saturated alkanes in the OLP produced. The infrared spectrum of the green gasoline showed characteristic bands of saturated hydrocarbons, like vibration characteristic bands of axial deformation of $\mathrm{CH}$ region $3000-2840 \mathrm{~cm}^{-1}$ corresponding function hydrocarbons, normal 
alkanes to more accurately associated with these is the presence of the $1373 \mathrm{~cm}^{-1}$ band relating to the deformation vibration of $\mathrm{CH}$ angular methyl groups [23, 24].

\subsection{Distillation curve}

The Fig.4 corresponding to distillation curve of the green gasoline, the percentage of which to $10 \%$ of distillate recovered, the distillation temperature is slightly higher than the value required (About $65^{\circ} \mathrm{C}$ ) standard by Agência Nacional de Petróleo, Gás Natural e Biocombustíveis (ANP/Brazil), but for all other values such as $50 \%, 80 \%, 90 \%$ and $100 \%$ of distillate recovered values are consistent with a standard distillation curve, thus confirming the efficiency of the production process for this distillate fraction.

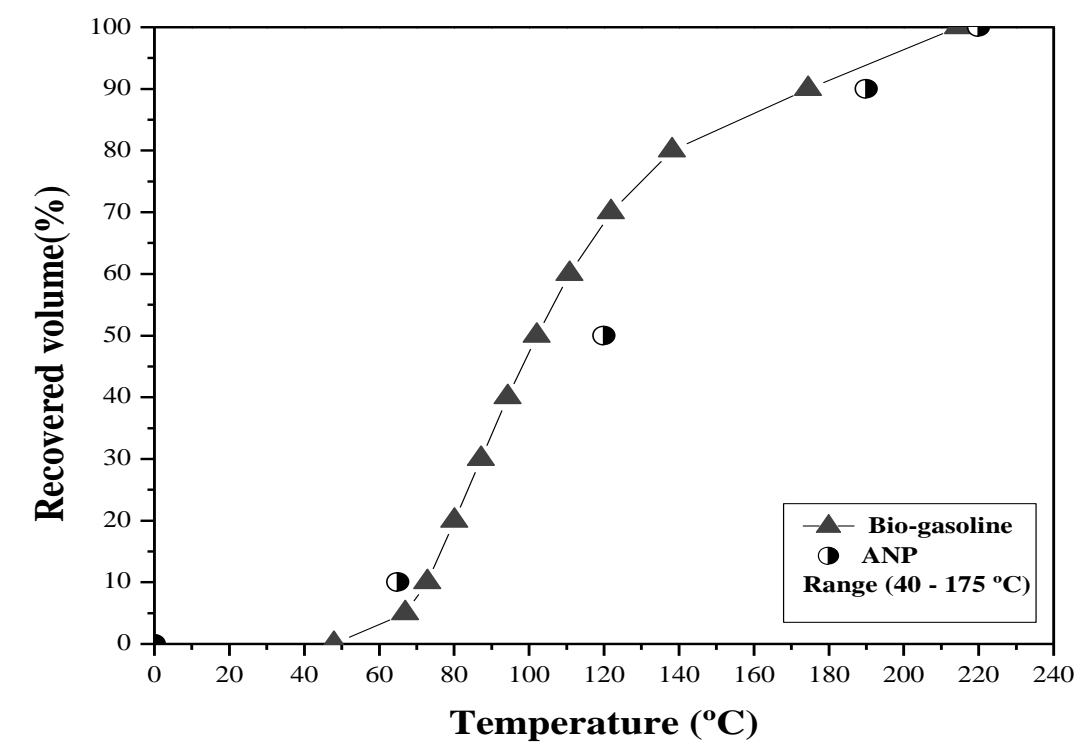

Figure 4: Distillation curve of the distilled fraction in the range $40-175^{\circ} \mathrm{C}$.

\subsection{Chromatographic analysis of the product (green gasoline)}

The GC-MS analysis of the green gasoline was conducted using a gas chromatograph coupled with a mass spectrometer as described in section 2.4.4. The chromatogram related to biofuel obtained in the distillation range $40-175^{\circ} \mathrm{C}$ (Fig. 5) through the analysis indicates the presence of the major peaks and their retention times, which are mainly present in the ranges between 2.5 and 7,5 min, and between 15 and 20 minutes (Table 4) in the presence of short hydrocarbons and long chains being predominant short chain hydrocarbons. 


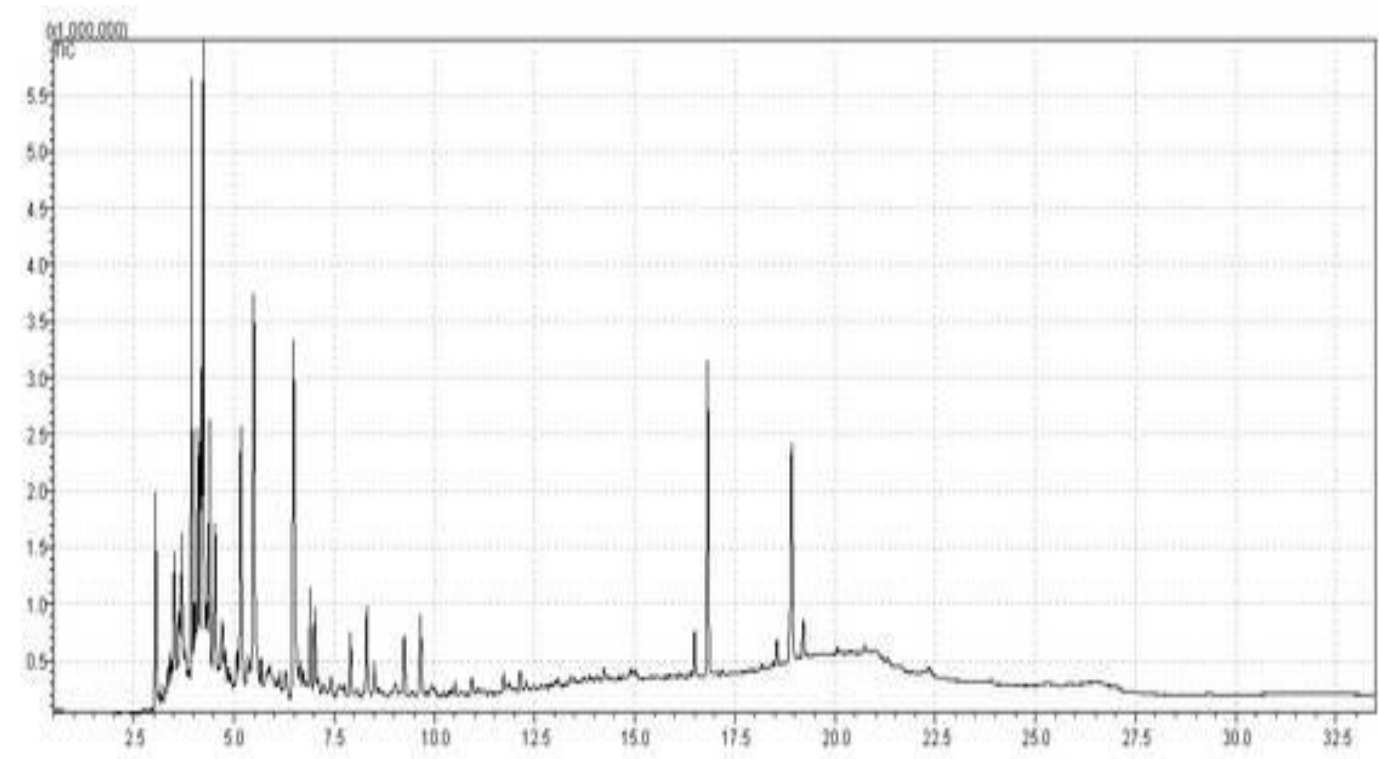

Figure 5: Chromatogram of biofuel regarding the range $40-175^{\circ} \mathrm{C}$.

With the retention times observed in Table 4, it can be stated that the ranges present of hydrocarbons are between $\mathrm{C} 6$ and $\mathrm{C} 28$, with higher amounts in the range of $\mathrm{C} 9$ through $\mathrm{C} 12$. One can also note that the latter is exactly the size range of hydrocarbon chains present in petroleum-derived gasoline [16, 17]. 
Table 4: Retention times (RT) intensity, levels and identification of peaks found in the distillation range

\begin{tabular}{|c|c|c|c|}
\hline Molecular Formula & Retention Time & Peak area & Area [\%] \\
\hline C6H12O & 3.044 & 3991950 & 2.91 \\
\hline C8H12 & 3.183 & 532751 & 0.39 \\
\hline С9H16 & 3.357 & 1285290 & 0.94 \\
\hline С10H18 & 3.397 & 793185 & 0.58 \\
\hline С9H16 & 3.442 & 1045292 & 0.76 \\
\hline C14H20NO3 & 3.512 & 4485016 & 3.27 \\
\hline C10H20 & 3.621 & 2811641 & 2.05 \\
\hline C9H13NO2 & 3.701 & 4470623 & 3.26 \\
\hline С7H14O & 3.800 & 1301907 & 0.95 \\
\hline C11H24 & 3.948 & 10584663 & 7.71 \\
\hline С13H28 & 4.022 & 2376871 & 1.73 \\
\hline C7H14O & 4.096 & 7289476 & 5.31 \\
\hline C13H26 & 4.181 & 6338579 & 4.62 \\
\hline C11H22 & 4.232 & 13711276 & 9.99 \\
\hline С16H30 & 4.342 & 2955432 & 2.15 \\
\hline C11H22 & 4.392 & 4886833 & 3.56 \\
\hline С13H26 & 4.525 & 4767103 & 3.47 \\
\hline С9H12 & 4.706 & 2665167 & 1.94 \\
\hline C12H24 & 4.783 & 602232 & 0.44 \\
\hline C11H20 & 4.863 & 261040 & 0.19 \\
\hline С6H11CIO & 5.078 & 803520 & 0.59 \\
\hline С12H26 & 5.175 & 6188510 & 4.51 \\
\hline C11H20 & 5.369 & 972407 & 0.71 \\
\hline С10H22O & 5.491 & 11894395 & 8.67 \\
\hline С12H24 & 5.683 & 441585 & 0.32 \\
\hline C6H12O2 & 6.485 & 12741466 & 9.29 \\
\hline С12H16 & 6.662 & 586731 & 0.43 \\
\hline С13H26 & 6.903 & 2189696 & 1.60 \\
\hline C9H18O & 7.015 & 1847082 & 1.35 \\
\hline С16H34 & 7.909 & 1339282 & 0.98 \\
\hline С14H28 & 8.311 & 1867430 & 1.36 \\
\hline C10H20O & 8.504 & 785298 & 0.57 \\
\hline C15H32 & 9.249 & 1172095 & 0.85 \\
\hline C15H32 & 9.657 & 1655949 & 1.21 \\
\hline C19H38 & 12.142 & 374176 & 0.27 \\
\hline С15H30O & 16.500 & 928483 & 0.68 \\
\hline $\mathrm{C} 18 \mathrm{H} 36 \mathrm{O} 2$ & 16.819 & 7128233 & 5.20 \\
\hline C16H22O4 & 18.554 & 462567 & 0.34 \\
\hline С20H38O2 & 18.917 & 5859739 & 4.27 \\
\hline С20H36O2 & 19.210 & 801964 & 0.58 \\
\hline С6H12O & 3.044 & 3991950 & 2.91 \\
\hline
\end{tabular}

The gas chromatography analysis (GC/MS) coupled with a mass balance, enabled the identification of the composition, as well as the percentage of each substance present in green gasoline (Table 5), among which are the normal paraffins, naphthenic, olefin, aromatic and oxygenated compounds whose calculated percentages were $52.76 \%$ of hydrocarbon and $47.24 \%$ of oxygenates, confirmed by $[16,17]$. 
Table 5: Chemical compositional analysis of fraction $40-175^{\circ} \mathrm{C}$ for the content of oxygenates and hydrocarbons.

\begin{tabular}{lcc}
\hline \multicolumn{1}{c}{ Parameters } & Amount (\%) \\
\hline Hydrocarbons & 52.76 \\
Normal paraffin & 15.78 \\
Naphthenic & 3.50 \\
Aromatics & 1.94 \\
Olefin & 31.54 \\
Oxygenates & 47.24 \\
\hline
\end{tabular}

It may be emphasized that despite the high content of oxygenates present in the green gasoline, these basically correspond to ketones, alcohols and esters having a very small quantity of carboxylic acids, as confirmed by physical and chemical analysis and the spectrum of IR. To the non-oxygenated hydrocarbon, the analytical results showed a high content of olefinic compounds about $59.78 \%$ of the total of hydrocarbon, and $29.87 \%$ in normal paraffinic, $6.63 \%$ in naphthenic and 3.68\% in aromatics. This result is confirmed by Hua (2008) [23], since the content found by Hua (2008) [23] was 84\%, predominantly in C5 and C6. While in this study the predominant olefinic compounds were found between $C 9$ and $C 13$ [23, 25]. It should also be noted that green gasoline produced is presented within the specifications established by [26] in relation to the composition of olefinic compounds, since the percentage thereof compared to the total composition corresponds to the $31.54 \%$, and required a maximum of $45 \%$ by the regulatory agency (ANP). It can be noted that the green gasoline produced need to be optimized, since, to low concentration of aromatic compounds and naphthenic can influence the resistance to detonation, but green gasoline produced, presents other compounds, such as normal paraffin, the that implies in greater stability or resistance detonating.

\section{CONCLUSION}

The thermal catalytic cracking of palm oil using sodium carbonate $20 \%(\mathrm{w} / \mathrm{w})$ and $450{ }^{\circ} \mathrm{C}$ in a pilot scale, which generated a dark organic liquid product called OLP despite generated hydrocarbons in the range of gasoline, the reaction was not as efficient, especially in relation to the performance parameter, and in the composition of green gasoline, which presented a high oxygenate content. However, in relation to other parameters of the OLP, the reaction was considered positive, since the properties of density, kinematic viscosity, acid value, amongst others is within the range specified by the Brazilian regulatory agencies [26], as well as, consistent with data in the literature. The bio-gasoline obtained after distillation of the PLO showed a composition of $52.76 \%$ of hydrocarbons (15.78\% of normal paraffinic, $3.5 \%$ naphthenic, $1.94 \%$ of aromatics and $31.54 \%$ of olefin) and $47.24 \%$ of oxygenates.

\section{ACKNOWLEDGMENTS}

CNPq for the scholarship and ELETROBRÁS S/A for the project financial support.

\section{REFERENCES}

1. Maher KD, Bressler DC. Pyrolysis of triglyceride materials for the production of renewable fuels and chemicals. Bioresource Technology. 2007 n. 98, p. 2351-2368, doi:10.1016/j.biortech.2006.10.025.

2. Santos CD, Bofim LM, Motta JAS, Rodrigues G, Nascimento AR, Araujo AS, Pedrosa AMG, Souza MJB. Estudo da pirólise de óleo de soja sobre peneiras moleculares micro e mesoporosas. Scientia Plena, Vol 5, n. 11, 2009.

3. Ong YK e Bhatia S. The current status and perspectives of biofuel production via catalytic cracking of edible and non-edible oils. Energy. 2009 n.35 p 111 - 119, doi:10.1016/j.energy.2009.09.001.

4. Ooi Y, Zakaria R, Mohamed AR, Bhatia S. Catalytic conversion of palm oil-based fatty acid mixture to liquid fuel. Biomass and Bioenergy. 2004 vol. 27 pp. 477-484, doi:10.1016/j.biombioe.2004.03.003. 
5. Suarez AZ, Meneghetti SMP, Meneghetti MR, Wolf CR. Transformação de triglicerídeos em combustíveis, materiais poliméricos e insumos químicos: algumas aplicações da catálise na oleoquímica. Química Nova, v. 30, p. 667-676, 2007.

6. Ma F, Hanna MA. Biodiesel production: a review. Bioresource Technology. 1999 v. 70, p.1-15, doi.org/10.1016/S0960-8524 (99) 00025-5.

7. Mellde RW, Maasing IM, Johansson TB. Advanced automobile engines for fuel economy Annu. Rev. Energy. 1989 n. 14, p. 425-444, doi: 10.1146/annurev.eg.14.110189.002233.

8. Wang $\mathrm{G}$, Yang $\mathrm{G}, \mathrm{Xu} \mathrm{C}$, Gao J. A novel conceptional process for residue catalytic cracking and gasoline reformation dual-reactions mutual control. Applied Catalysis A: General. 2008 p. 98-105, doi:10.1016/j.apcata.2008.02.031.

9. Botton V, Riva D, Simionatto EL, Wiggers VD, Ender L, Meier HF, Barros AAC. Craqueamento termo-catalítico da mistura óleo de fritura usado de estamparia têxtil para a produção de óleo com baixo índice de acidez. Quím. Nova. 2012 vol. 35 nº.4 São Paulo.

10. Mancio AA, da Costa KMB, Ferreira CC, Santos MC, Lhamas DEL, da Mota SAP, et al. Thermal catalytic cracking of crude palm oil at pilot scale: Effect of the percentage of $\mathrm{Na} 2 \mathrm{CO} 3$ on the quality of biofuels. Industrial Crops and Products. 2016, 91:32-43, doi:10.1016/j.indcrop.2016.06.033.

11. Ahmad M, Farhana R, Raman AAA, Bhargava SK. Synthesis and activity avaluation of heterometallic nano oxides integrated ZSM-5 catalysts for palm oil cracking to produce biogasoline. Energy Conversion and Management. 2016 vol 119 pg 352 - 360, doi.org/10.1016/j.enconman.2016.04.069.

12. Wiggers VR, Meier HF, Wisniewski A, Barros AAC, Maciel MRW. Biofuels from continuous fast pyrolysis of soybean oil: A pilot plant study. Bioresource Technology. 2009 100(24): 6570-7, doi:10.1016/j.biortech.2009.07.059.

13. Dandik L, Aksoy, H.A. Pyrolysis of used sunflower oil in the presence of sodium carbonate by using fractionating pyrolysis reactor. Fuel Processing Technology. 1998 v.57, p.81-92, doi: 10.1016/S01406701 (99) 96211-2.

14. Twaiq FAA, Mohamad AR, Bhatia S. Performance of composite catalysts in palm oil cracking for the production of liquid fuels and chemicals. Fuel Processing Technology. 2004, 85(11):1283-300, doi:10.1016/j.fuproc.2003.08.003.

15. Mota SAP, Mancio AA, Lhamas DEL, de Abreu DH, da Silva MS, dos Santos WG, et al. Production of green diesel by thermal catalytic cracking of crude palm oil (Elaeis guineensis Jacq) in a pilot plant. Journal of Analytical and Applied Pyrolysis. 2014; 110:1-11, doi:10.1016/j.jaap.2014.06.011.

16. Szklo AS, Uller VC. Fundamentos do refino d petróleo: tecnologia e economia. Rio de Janeiro: Interciência; 2008.

17. Thomas JE. Fundamentos de Engenharia de Petróleo. Rio de Janeiro: Interciência: Petrobras, 2001.

18. Akinola FF, Oguntibeju OO, Adisa AW, Owojuyigbe OS. Physicochemical properties of palm oil from different palm oil local factories in Nigeria. Food, Agriculture and Environment (JFAE). Online ISSN: 1459-0263Year: 2010, Vol. 8, Issue 3\&4, pages 264-269. Publisher: WFL.

19. Umakanta J, Das KC, Kastner JR. Comparison of the effects of $\mathrm{Na}_{2} \mathrm{CO}_{3}, \mathrm{Ca}_{3}\left(\mathrm{PO}_{4}\right)_{2}$, and $\mathrm{NiO}$ catalysts on the thermochemical liquefaction of microalga Spirulina platensis. Applied Energy. 2012 368-375, doi.org/10.1016/j.apenergy.2012.03.056.

20. Konwer D, Taylor SE, Gordon BE, Otvos JW, Calvin M. Liquid fuels from Mesua ferrea L. seed oil. 2014, vol. 2, Issue 9 ISSN 232-869.

21. Siswanto DY, Salim GW, Wibisono N, Hindarso H, Sudaryanto Y, Ismadji S. Gasoline production from palm oil via catalytic cracking using MCM-41: determination of optimum condition. ARPN. Journal of Engineering and Applied Sciences. 2008.

22. Prado CMR, Antoniosi Filho NR. Production and characterization of the biofuels obtained by thermal cracking and thermal catalytic cracking of vegetable oils. Journal of Analytical and Applied Pyrolysis. 2009;86(2):338-47, doi:10.1016/j.jaap.2009.08.005.

23. Hua T, Chunyi LI, Chaohe Y, Honghong S. Alternative Processing Technology for Converting Vegetable Oils and Animal Fats to Clean Fuels and Light Olefins. Chinese Journal of Chemical Engineering, 200816 (3) 394-400.

24. Silverstein RM, Webster FX, Kiemle DJ. Identificação espectrométrica de compostos orgânicos. Rio de Janeiro: Livros Técnicos e Científicos, 2007.

25. Idem RO, Katikaneni SPR, Bakhshi NN. Catalytic conversion of canola oil to fuels and chemicals: Roles of catalyst acidity, basicity and shape selectivity on product distribution. Fuel Process. Technol. 1997 51, 101-125, doi:10.1016/S0378-3820(96)01085-5.

26. Agência Nacional do Petróleo, Gás Natural e Biocombustíveis - ANP. Resolução No 40, de 25 de outubro de 2013. Diário Oficial da União, Brasília, DF.

27. Agência Nacional da Vigilância Sanitária (ANVISA). Resolução no 482, de 23 de setembro de 1999. Diário Oficial da União, Brasília, DF. 